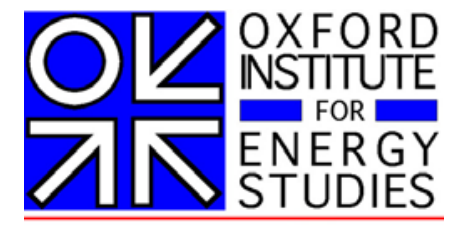

\title{
North African Oil and Foreign Investment in Changing Market Conditions
}

\author{
Bassam Fattouh
}

Centre for Financial and Management Studies, SOAS

and

Oxford Institute for Energy Studies

July 2008

WPM 37 
The contents of this paper are the sole responsibility of the author. They do not necessarily represent the views of the Oxford Institute for Energy Studies or any of its Members.

Copyright (C) 2008

\section{Oxford Institute for Energy Studies}

(Registered Charity, No. 286084)

This publication may be reproduced in part for educational or non-profit purposes without special permission from the copyright holder, provided acknowledgment of the source is made.

No use of this publication may be made for resale or for any other commercial purpose whatsoever without prior permission in writing from the Oxford Institute for Energy Studies.

ISBN

978-1-901795-75-2 


\section{CONTENTS}

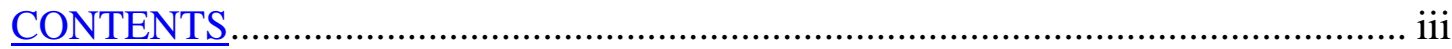

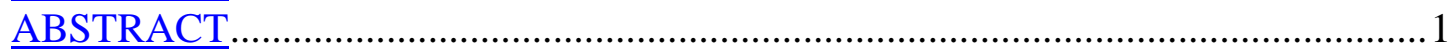

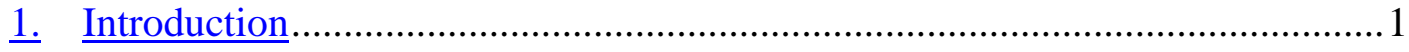

2. Libya: Access but with Tough Fiscal Terms .............................................. 4

2.1 Oil Contracts and Current Fiscal Terms …................................................5

3. Algeria: Oil Policy Reversals................................................................... 8

3.1 Contracts and Fiscal Terms .................................................................. 10

4. Egypt: Mature area with Massive Foreign Interest........................................11

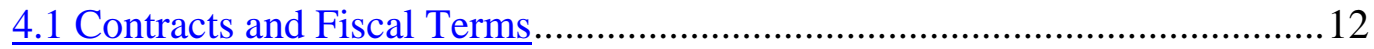

5. Sudan: the Land of Asian NOCs.................................................................. 15

5.1 Oil Contracts and Fiscal Terms...............................................................17

6. $\quad$ Assessment and Evaluation.........................................................................19

6. 1 National Oil Companies and Reliance on Foreign Oil Companies .............. 19

6.2 Oil Contracts, Fiscal Terms and Investment..............................................22

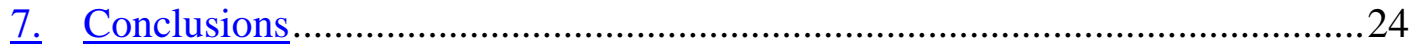

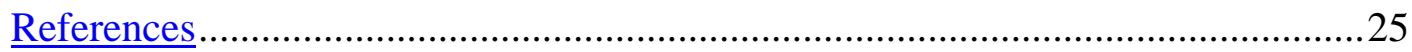

Appendix I: Licensing Rounds in Libya ......................................................... 27

Appendix II: Exploration and Production Blocks in Algeria...................................31

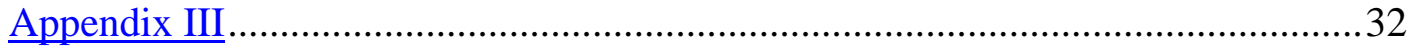

Appendix IV: Exploration and Production Blocks in Sudan ...................................33

Table 1: Year on Year Change in Oil Production (thousand barrels per day) ................2

Table 2: Proven Oil Reserves in Billion of Barrels ....................................................

Table 3: Libyan Oil Output by Oil Company ........................................................... 5

Table 4: Algerian Fiscal Terms........................................................................... 11

Table 5: Egypt: Major Producing Fields and Operators ............................................ 13

Table 6: Egypt's Production Sharing Agreement and Fiscal Terms............................15

Table 7: Oil Production by Block/Operator, 2007 ...................................................... 16

Table 7: Typical Company Take in Sudan from US\$ 100 million of Gross Revenues18

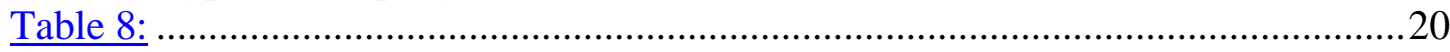

Figure 1: Oil Production in Africa in 2006 (thousand barrels per day) .........................2

Figure 2: Structural Trend in Primary Production in Algeria ...................................... 19

Figure 3: Percentage of Production by Producing Block in 2006 ..............................17 


\begin{abstract}
We analyse the oil contracts and fiscal terms used by North African countries (Algeria, Libya, Egypt and Sudan) and the evolution of foreign oil companies' involvement in their oil sectors. Although the relationship between foreign oil companies and the governments of North Africa has witnessed major transformations over the years and has taken different shapes across countries depending on country-specific factors, there are some important similarities with regards to the importance of foreign investment. North African countries' oil sectors are still heavily reliant on foreign oil companies and this reliance is likely to increase further if they are to meet their ambitious expansion plans. The recent rise in oil prices and the limited opportunities available elsewhere meant that foreign oil companies had to deal with more confident and assertive governments that are demanding a higher stake in the oil rent. The effectiveness in which governments and foreign oil companies adjust to this new reality will determine the extent and the pace of the future development of these countries’ oil sectors.
\end{abstract}

\title{
1 Introduction
}

The oil sectors in the North African countries of Algeria, Libya, Egypt and Sudan have witnessed major transformations in the past decade or so. In Algeria, government reforms in the mid 1980s resulted in the entry of a wide range foreign oil companies to an oil sector previously dominated by the state-owned oil company. In Libya, the lift of US sanctions and the opening of the oil sector to foreign investment through a series of licensing rounds created a new dynamism not seen since the mid 1950s when the country's oil industry kicked off. Egypt's oil policy of building partnerships with foreign oil companies makes it one of the most attractive countries for foreign investment despite its mature oilfields. In Sudan, Asian national oil companies transformed the prospects of the country's oil sector. Since 1999, Sudan's oil production has been rising steadily enabling the country to join the club of oil exporters.

The focus on this sub-region of Africa is important for a number of reasons. First, oil production in these countries reached $5 \mathrm{mb} / \mathrm{d}$ in 2006 accounting for almost half of oil production in Africa (Figure 1). More important is the pattern of production growth in the past few years. With the exception of Egypt where output has been in decline since 1993, Algeria, Libya and Sudan have achieved positive output growth in the past few years. During the period 1999-2006, these three countries increased their production by more than $1.2 \mathrm{mb} / \mathrm{d}$ (see Table 1). This increase in capacity proved vital at times when oil market conditions were getting tighter. 
Figure 1: Oil Production in Africa in 2006 (thousand barrels per day)

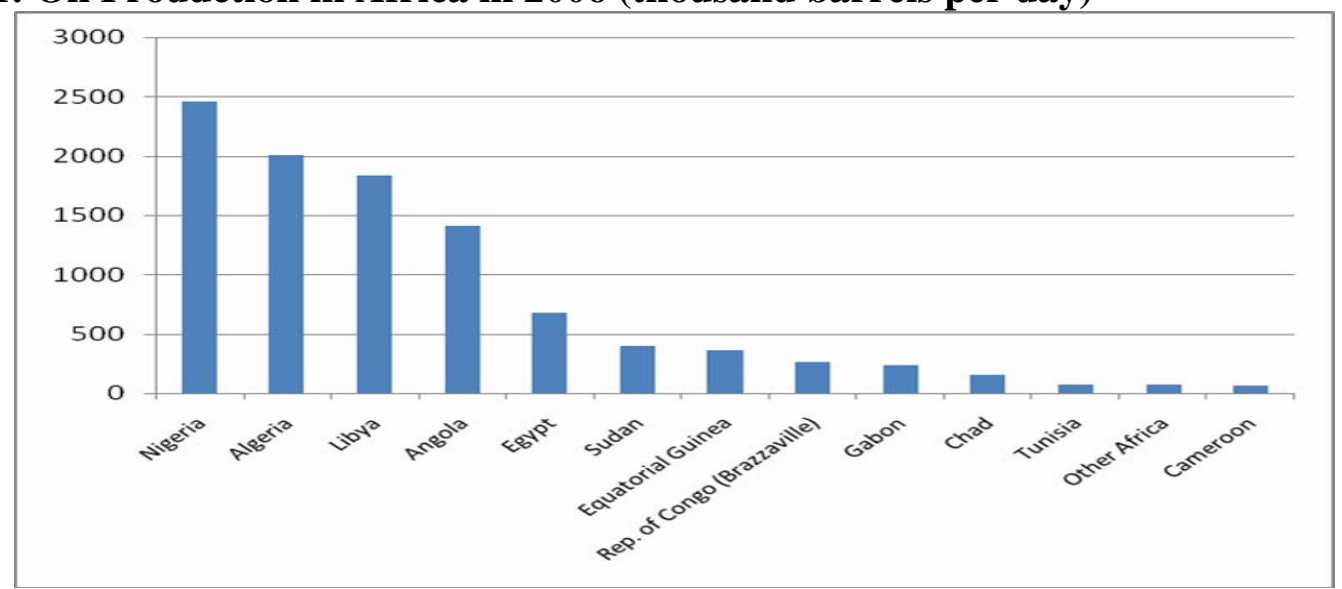

Source: BP Statistical Review of World Energy 2007

Table 1: Year on Year Change in Oil Production (thousand barrels per day)

\begin{tabular}{|lrrrrrrrrr|}
\hline Country & $\mathbf{1 9 9 9}$ & $\mathbf{2 0 0 0}$ & $\mathbf{2 0 0 1}$ & $\mathbf{2 0 0 2}$ & $\mathbf{2 0 0 3}$ & $\mathbf{2 0 0 4}$ & $\mathbf{2 0 0 5}$ & $\mathbf{2 0 0 6}$ & Total \\
Algeria & 55 & 63 & -16 & 118 & 2 & 94 & 70 & -11 & 544 \\
Egypt & -29 & -46 & -23 & -7 & -2 & -28 & -25 & -19 & -179 \\
& & & & & 11 & & & & \\
Libya & -55 & 50 & -48 & -52 & 0 & 139 & 127 & 84 & 355 \\
Sudan & 51 & 111 & 37 & 22 & 22 & 70 & 30 & 42 & 385 \\
\hline
\end{tabular}

Source: BP Statistical Review of World Energy 2007

Second, the proven oil reserves of these four countries are estimated at around 64 billion barrels in 2006 constituting more than 55\% of Africa's total oil proven reserves. More important is the large increase in the size of estimated proven reserves over the past two decades. In Libya, the size of proven oil reserves almost doubled increasing from 22.8 billion barrels in 1986 to 41.4 billion barrels in 2006. In Algeria, the increase in the size of proven reserves was more modest but still significant rising from 8.8 in 1986 to 12.3 billion barrels in 2006. In 1986, Sudan's proven oil reserves stood at 300 million barrels while in 2006 proven oil reserve were estimated at 6.4 billion barrels. Due to the long civil war in Sudan and the sanctions in Libya, exploration activity in these countries was kept at a minimum. The volume of proven reserves is likely to increase as exploration intensifies. 
Table 2: Proven Oil Reserves in Billion of Barrels

\begin{tabular}{|c|c|c|c|c|}
\hline Country & $\begin{array}{c}\text { at end } \\
\mathbf{1 9 8 6}\end{array}$ & $\begin{array}{c}\text { at end } \\
\mathbf{1 9 9 6}\end{array}$ & $\begin{array}{c}\text { Change } \\
\text { at end }\end{array}$ & $\begin{array}{c}\text { over 20 } \\
\text { years }\end{array}$ \\
Algeria & 8.8 & 10.8 & $\mathbf{1 2 . 3}$ & 3.5 \\
Egypt & 4.5 & 3.8 & 3.7 & -0.8 \\
Libya & 22.8 & 29.5 & $\mathbf{4 1 . 5}$ & 18.7 \\
Sudan & 0.3 & 0.3 & $\mathbf{6 . 4}$ & 6.1 \\
\hline Total & & & & \\
Africa & $\mathbf{5 8 . 0}$ & $\mathbf{7 4 . 9}$ & $\mathbf{1 1 7 . 2}$ & $\mathbf{5 9 . 2}$ \\
\hline
\end{tabular}

Source: BP Statistical Review of World Energy 2007

Third, North Africa is one of the few regions in the developing world where oil companies have full access to reserves and access to reserves with the participation of the state-owned company. As we discuss below, foreign oil companies have always formed the backbone of the North African oil industry. This was reinforced in the last decade where their share of output continues to rise. The region also provides a rich framework for comparative analysis regarding the evolution of the relationship between foreign oil companies and the domestic governments. The relationship has been affected by many country specific factors including the competence of the state oil company, the country's hydrocarbon potential, and whether a country has been subject to sanctions. Focusing on North Africa is also interesting since for most of their modern history, economies such as those of Egypt, Libya or Algeria have been heavily dominated by their states and state actors (see for instance Richards and Waterbury, 1996). Allowing private investors, not to mention foreign private investors, into this strategic sector constitutes an important anomaly. In some countries such as Egypt, this relationship has survived very extreme market conditions: the slack market and low oil price environment of the 1980s and most of the 1990s and the tight market conditions and high oil price environment of the past few years. This begs important questions: what have been the underlying bases for this relationship? Can this framework be generalised into different contexts?

Finally, the region provides a rich framework to compare fiscal regimes both across countries and over time. The oil contracts and fiscal terms vary considerably across the North African producers. The production sharing agreement (PSA) remains among the most common type of agreement used in North Africa and elsewhere in the world. These agreements however take different forms and the way the state participates in joint companies varies considerably across countries. In Algeria, the state retains 51\% share of the joint venture. In Libya, there is no such requirement but the national oil company usually retains a high share of the venture. In Egypt, a foreign oil company is obliged to form an Egyptian based stock joint company with each of the partners holding $50 \%$ of the newly created entity. In Sudan, the state participates in some but not all projects and its share is often low not exceeding the $10 \%$. The government take of oil revenue also varies widely across North African producers where Libya's fiscal terms are considered as one of the harshest in the world while those of Sudan and Egypt are considered as relatively attractive. In addition to cross-country differences, the hydrocarbon law and fiscal terms have 
evolved differently. While in Egypt and Sudan the hydrocarbon law and fiscal terms remained highly stable, in Algeria and Libya these were adjusted regularly to reflect changing market conditions. The tight oil market conditions of the past few years have resulted in major changes to fiscal terms in Algeria and Libya. In the future, the main issue in these countries will not be one of access to reserves, but whether the fiscal terms on offer will prove attractive to foreign oil companies.

This paper is divided into three sections. In sections 2, 3, 4 and 5 we provide a brief description of the foreign companies' involvement in each of these countries' oil sectors and the fiscal regime in use. In section 6 , we draw some lessons based on the experience of North African oil producers. Section 7 concludes.

\section{Libya: Access but with Tough Fiscal Terms}

Despite its reliance on foreign oil companies, Libya has proved over the years its ability to impose tough fiscal terms by timing its renegotiations with favourable changes in oil market conditions, introducing innovative bidding procedures, attracting different types of oil companies, and using negotiations tactics that aim at getting maximum concession from one of its partners and then applying the new terms to the rest of oil companies. Libya has been in a position to use such harsh terms partly because of its geographic location at the door of Europe and partly because of its attractive geological characteristics. It is considered a high quality oil province consisting largely of sweet crude oil and characterised by low cost of production. Limited opportunities for access by foreign oil companies to high quality reserves elsewhere has increased Libya's attractiveness especially that the country is relatively under-explored due, in part, to the imposition of sanctions which limited exploration activity.

The imposition of long-term sanction on Libya affected foreign oil companies' access with adverse consequences on investment in the upstream sector. In the 1980s, Libya was hit by a series of US sanctions which caused the departure of all US oil companies. Exxon and Mobil (now ExxonMobil) were the first to exit in 1982. Amerada Hess, Conoco, Grace Petroleum, Marathon, and Occidental exited the Libyan oil sector in 1986 following the US Executive Order 12543 which prohibited commercial transactions with Libya. In 1996, the US introduced the Iran and Libya Sanction Act directed towards persons that make investments that contribute to the enhancement of Libya's petroleum resources or enhances Libya's ability to develop its petroleum resources. The sanctions had adverse impact on investment in the oil sector. The Libyan authorities had no option but to negotiate and try to attract European oil firms in an attempt to counteract the impact of US sanctions.

The lift of US sanctions in 2004 and Libya's opening to the west created new opportunities which companies have been eager to exploit. US oil companies have been making their way back into Libya through participating in the exploration rounds and/or renegotiating the resumption of operations they left behind. In 2004, Libya offered substantial new acreage under the terms of EPSA IV. NOC has also been busy renegotiating the outdated contracts with foreign oil companies already operating in the country.

The table below shows the allocation of Libyan oil production in 2006 estimated at 1.7 million $\mathrm{b} / \mathrm{d}$ across the various operators. As can be seen from this table, the wholly-owned affiliates of 
NOC namely Arabian Gulf Oil Company (AGOCO), Zueitina Oil Company (ZOC), Waha Oil Company (WOC), and Sirte Oil Company (SOC) control a large percentage of oil production. Until recently, these state-owned oil companies used to fund their operations directly from the government budget and their sale proceeds used to flow to the treasury. The re-entry of US oil companies has changed the structure of WOC and ZOC where the foreign partner is playing a major operational role. The table also shows the wide range of foreign oil companies operating in Libya indicating that the presence of the sanction regime did not hamper the entry of foreign oil companies. However, it affected the mix of foreign oil companies operating in Libya with large presence of European oil companies.

\section{Table 3: Libyan Oil Output by Oil Company}

\begin{tabular}{|lcc|}
\hline \multicolumn{1}{|c|}{ Company } & $\begin{array}{c}\text { Production in 2006 } \\
\text { (thousands } \\
\text { barrels/day) }\end{array}$ & Percentage \\
Arabian Gulf Oil & 436 & $24.76 \%$ \\
Company & & \\
Waha Oil Company & 340 & $19.31 \%$ \\
(WOC) & 286 & $16.24 \%$ \\
Eni & 256 & $14.54 \%$ \\
Repsol & 101 & $5.74 \%$ \\
Sirt Oil Company (SOC) & 112 & $6.36 \%$ \\
Wintershall & 97 & $5.51 \%$ \\
Veba Oil Operations & & $3.41 \%$ \\
ZUEITINA Oil & 60 & $4.15 \%$ \\
Company (ZOC) & 73 & $100.00 \%$ \\
\hline Other companies & 1761 & \\
Total & & \\
\hline
\end{tabular}

Notes: The Arabian Gulf Oil Company an exploration company in which the shares of the British petroleum company (BP) were nationalised in concession No. 65 covering the Sarir field; Sirte Oil Company (SOC) is the most integrated and one of the largest operating subsidiaries of the National Oil Corporation of Libya.

Source: Libyan National Oil Company Annual report 2006

\subsection{Oil Contracts and Current Fiscal Terms}

Libya has used different types of petroleum agreements: concessions, participation and EPSAs. In what follows, we focus on the different generation of EPSA which has been the main vehicle for the recent entry of oil companies into Libya.

The first Libyan Petroleum Law No.25 enacted in 1955 was innovative in many aspects compared to the concessionary systems adopted in most of the Middle East Gulf. Rather than granting concessions over large areas, it limited the size of single concessions to 75,000 square $\mathrm{km}$ which ensured that the oil sector was not being dominated by few big oil companies. The law also set a relinquishment requirement so firms that lease blocks and do not engage in exploration and development activity could lose their concession to other competitors willing to develop the block. The 1955 Petroleum Law fostered competition and succeeded in attracting the reluctant 
majors and a wide range of other smaller companies which had few available upstream opportunities outside Libya. This gave the Libyan government a powerful bargaining position. When oil companies began to make important discoveries in the 1960s, the government was able to step in and demand higher share of oil revenues by increasing the royalty rate and by amending the existing law to give the government the option to participate up to $30 \%$ in joint ventures (IEA, 1996).

The tight oil market conditions of the 1970s strengthened further the bargaining position of the new Libyan regime vis-à-vis the concessionaires. In September 1970, the government reached an agreement with Occidental where this independent company agreed to pay income taxes on the basis of increased posted prices and to make retroactive payment to compensate for the lost revenue since 1965. Soon after, all other companies operating in Libya submitted to the new terms. As a result of this agreement, other Middle East oil producers invoked the most favoured nation clause and made it clear that they would not accept anything less than the terms granted to Libya. The negotiations conducted in Tehran resulted in a collective decision to raise the posted price and increase the tax rate. The Tehran agreement resulted in better fiscal terms than those negotiated in Libya and thus the Libyan government reopened negotiations with foreign oil companies to bring the terms in line with the Tehran agreement (Seymour, 1980; Skeet, 1988).

During the period 1971-1973, the Libyan government began to revise existing concessions in favour of $51 \%$ participation agreements with the state oil company, the Libyan National Oil Corporation (NOC) created in 1970. After months of negotiations, many oil companies accepted the new participation agreement including BP, Agip, Occidental, Marathon, Amerada Hess and Conoco. For those oil companies that rejected the new participation deal the government issued a decree in September 1, 1973 nationalizing 51\% of their concessions. This has been the most radical decision that the Libyan government has ever taken against foreign oil companies (Gurney, 1996). During the 1972-1974, the government also managed to increase the royalty from $12.5 \%$ to $16.67 \%$ and raised taxes gradually from $55 \%$ to $65 \%$. The final blow to foreign oil companies' position was the introduction of Law No. 82 in 1973 which shifted the power of pricing crude oil from the foreign oil companies to the government. The new law postulated that the Petroleum Ministry would set the posted price on the basis of which all royalties and taxes were calculated. As a result of these measures, Libya controlled around $84 \%$ of all oil proceeds by 1973 (Otman, 2007). This however came at a cost where exploration and development activity slowed down markedly following the nationalisation process.

In 1973, Libya introduced exploration and production sharing agreements known as EPSA I as a means for future involvement of foreign oil companies in the country. EPSA I did not follow the conventional production sharing contract and was different in some important aspects. One important difference was that the contracts did not offer any part of oil production for cost recovery. The oil company was entitled to receive a fixed tax-free share of oil production ranging from $15 \%$ for onshore and $19 \%$ for offshore blocks. Furthermore, the new EPSA allowed the government greater supervisory and management control over operations through the formation of management committees. The government also introduced exploration obligations where the foreign oil company was obliged to conduct exploration with a schedule of seismic surveys. Between 1973-1978, the Libyan government forced existing companies to relinquish some of 
their unused blocks which were then offered to foreign companies under a second generation of exploration and sharing agreement (EPSA II) whose terms were even less attractive than EPSA I (Gurney, 1996). Such harsh terms did not attract enough foreign interest and the oil sector witnessed a contraction in exploration and development activities. This affected the development of marginal and small fields which proved to be uneconomical under the existing terms.

The low oil price environment of the 1980s, the imposition of sanctions on Libya and oil companies' increased access to new reserves outside OPEC forced the Libyan authorities to revise their existing production sharing contracts. In 1988, NOC introduced a third generation of exploration and production sharing agreement (EPSA III) which was more attractive than previous ones (Gurney, 1996). For the first time, Libya agreed to provide foreign firms with a percentage of oil against which oil companies can deduct exploration and development costs. The government hoped that these more attractive fiscal terms would attract foreign players and increase exploration activity. Despite the very generous fiscal terms, these were overshadowed by low oil prices and the tightening of sanctions imposed on Libya.

In 2004, substantial new acreage was offered under the terms of EPSA IV. The high interest shown by foreign oil companies during these the last three licensing rounds may suggest that Libya has been offering attractive fiscal terms (see Appendix 1). But quite the contrary, the Libyan terms have been described as the toughest in the world. In what follows, we describe the EPSA signed between the Libyan NOC and Verenex Energy and its partner MEDCO for area 47 granted under the first licensing round. EPSA IV follows the conventional PSA structure but there are some major differences. Under EPSA IV, the government followed new procedures with sealed-bid rounds, non-negotiable conditions, selection criteria (based on contractor share, exploration commitments, bonuses, parallel investment and local content), pre-qualification procedures and minimum expenditure commitment. Unlike EPSA III, awards were granted for companies that made the highest bid on the share of gross production going to NOC. This bidding parameter is usually referred to as the production factor while the remaining share going to the contractor is referred to as 'cost recovery'. This can be considered as novelty as the share going to the national oil company is usually pre-determined in the model contract or subject to negotiation. In effect, this production factor acts like a royalty since it is taken from gross output and is not accessible to the foreign investor. In our example, the bid yielded a production factor of $86.3 \%$ or a cost recovery bid of $13.7 \%(100 \%-86.3 \%)$. This means that the company has to recover its exploration, development and operational costs from its $13.7 \%$ share of production.

In case of a tie on the production factor, the company offering the highest bonus would receive the licensing award (Johnston, 2005). Thus, the companies had to compete on bonus payments as well. As can be seen from the tables above, the bonuses were quite high in some cases especially in the first round of bidding. That being said there is a large divergence in the amount of bonuses paid varying from zero to $\$ 25.6$ million. Bonuses are the most harmful from the view of the contractor as these are paid regardless of whether a discovery is made. Furthermore, the contractor is not allowed to recover bonus payments from cost oil.

The new agreements also give the option for NOC to participate in the venture if a commercial discovery is made. In this case, NOC is said to be carried through the exploration phase. In other words, it has the option to take a working interest in the venture without reimbursing the 
exploration costs incurred by the contractor but it would pay its share of development costs. In the example of Verenex, the Libyan National Oil Company (NOC) has the option to be carried through exploration and obtain a 50\% working interest of the venture. In return, NOC agrees to pay $50 \%$ of capital expenditure. The NOC is also carried further through development phase where it would pay $86.3 \%$ of the venture's operating expenditures. Until the contractor recovers his costs, the entire $13.7 \%$ share of production goes to the contractor. Once the contractor recovers his costs, the difference (i.e. profit oil) is shared between the contractor and NOC based on two sliding scales: $\mathrm{R}$ factor calculated as the ratio of accumulated receipts by the contractor to the accumulated capital expenditure (R factor) and the current year total project production rate ( $\mathrm{P}$ factor). The share of profit oil accruing to the contractor in each quarter is equal to: $\mathrm{R} \times \mathrm{P} \times$ Profit Oil. As can be seen from this example, the contractor take under EPSA IV is relatively low. Furthermore, there are also limits on how much the oil company can benefit from the upside potential of its investment. In fact, the overall government take for EPSA IV blocks averaged around 88\% which is considered as one of the highest in the world (Johnston, 2005). The Libyan case illustrates that despite its reliance on foreign oil companies, Libya has proved over and over again its ability to impose tough fiscal terms by timing its renegotiations with favourable changes in oil market conditions, The pressures from long sanctions and the desire to re-establish political and economic links with the West do not seem to have changed Libya's approach towards dealing with foreign oil companies.

\section{Algeria: Oil Policy Reversals}

Algeria's relationship with foreign oil companies have passed through many phases. Algeria was one of the first OPEC members to nationalise its oil industry. In 1970, the Council of the Revolution, the highest political authority in the country at that time, announced the expropriation of a number of companies including Shell and Mobil. By the end of the 1970, all non-French companies' assets were nationalised (Aissaoui, 2001). It was a matter of time before the Algerian authorities turn their attention to French companies, which dominated the Algerian energy sector. In 1971, the Algerian presidency announced the partial nationalisation of concessions held by the French companies which resulted in the Algerian government holding $51 \%$ of their concessions; the total nationalization of the gas sector; and the total nationalisation of oil and gas pipelines companies. The Algerian government continued to harden its grip over the oil sector. By 1972 it controlled about 77\% of crude oil production. Following the departure of foreign oil companies later in the mid 1970s, the government's share of oil production rose to 80\%. In 1980, the Algerian authorities refused to renew the association agreements with Total. This resulted in the government having complete control over the oil sector. The nationalisation of the Algerian oil industry did not preclude foreign oil companies' participation in upstream oil projects. However, the terms on offer were so restrictive that foreign companies were not encouraged to enter into partnerships with Sonatrach, the Algerian national oil company. By early 1980s, the responsibility of exploration development and production fell solely on Sonatrach.

The drive behind nationalisation however did not last for long. The fall in oil revenues in the 1980s, the sharp decline in the number of developed wells between 1980 and 1986, and the fall in oil output from $1.27 \mathrm{mb} / \mathrm{d}$ in 1979 to around $1 \mathrm{mb} / \mathrm{d}$ in 1983 forced the government to reverse its oil policy (IEA, 1996). These developments also exposed Sonatrach’s limitations especially in 
acquiring the technology needed to combat the decline in output of mature fields. As a result, the Algerian authorities had no option but to introduce a new hydrocarbon law and revise the fiscal terms in an attempt to attract foreign investment into exploration, development and enhanced recovery mechanisms. Foreign oil companies seized the opportunity to enter into this resource rich country. Over the 1990s, foreign oil companies established a dominant position in Algeria's hydrocarbon sector mainly in partnership with Sonatrach. According to Aissaoui, (2001), between 1987 and 2000 exploration budgets totalled $\$ 1.5$ billion which resulted in more than 30 discoveries representing reserves of 7 billion barrels of oil in place. The new changes in the hydrocarbon law also permitted foreign investment in mature producing oil fields allowing Sonatrach to attract foreign investment in EOR schemes to mature oil fields, which has always been the national oil company's top priority.

This drive continued for most of this decade. Since 2001 Algeria has awarded around 43 exploration and development contracts through six rounds of licensing and achieved investment of $\$ 3.5$ billion, $\$ 2$ billion of which was invested by foreign oil companies. This resulted in the entry of diverse players into Algeria's oil sector including Asian national oil companies (see Map in the Appendix II). Interestingly, Algeria has been able to attract a large range of players to its upstream sector and like Libya it avoided heavy dependence on super-majors. Small independent oil companies such as Maersk Oil, Amerada Hess, and Anadarko play an important role in Algeria's upstream sector. Since the reopening of Algeria's oil sector in the mid 1980s, foreign oil companies have increased their presence in Algerian upstream oil. While in 1995 foreign companies in partnership with Sonatrach accounted for less than 1\% of Algeria's total oil production, this ratio increased close to 30\% in 2006 (see Figure 2 below). As exploration and development activity accelerate, foreign companies' share of total output is expected to increase.

Figure 2: Structural Trend in Primary Production in Algeria

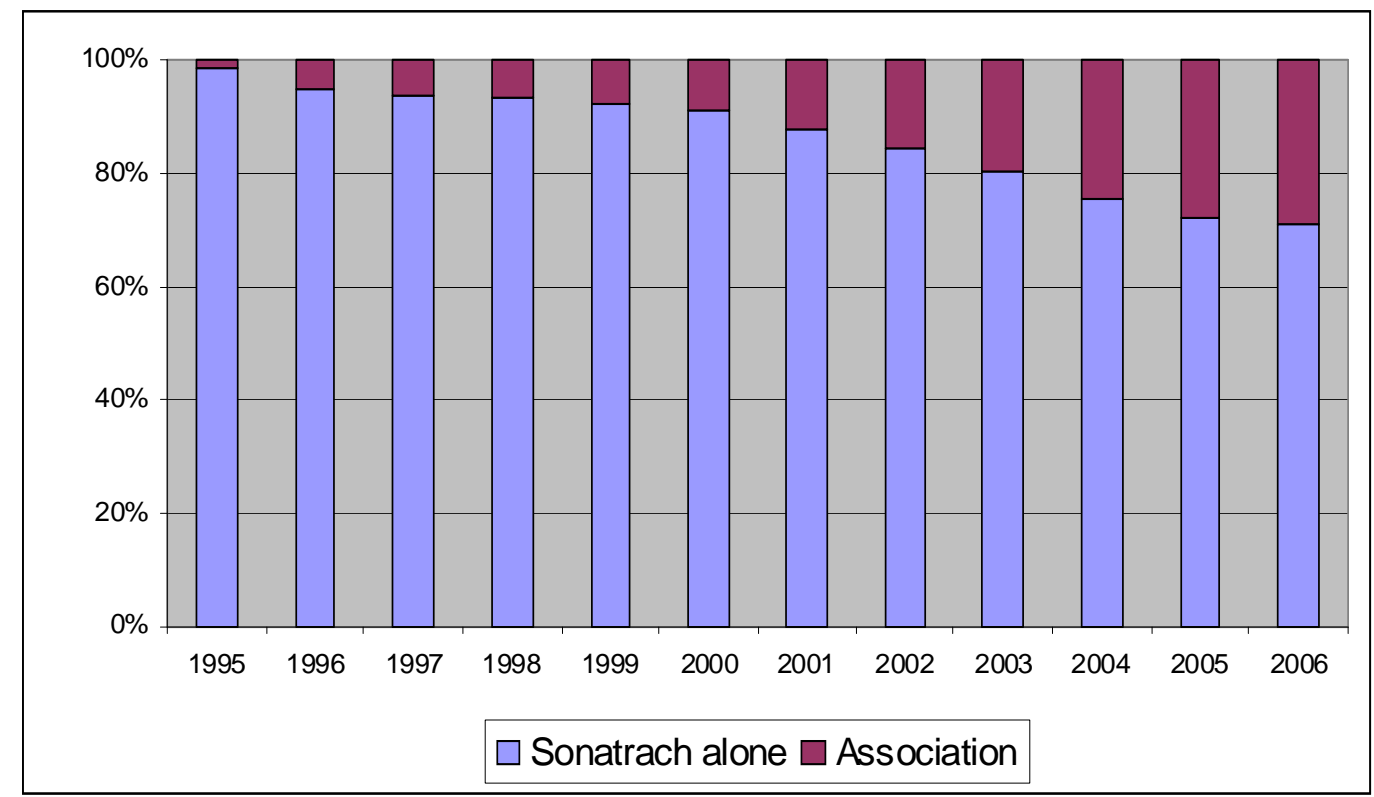

Source: Sonatrach Annual Report 2006 


\subsection{Contracts and Fiscal Terms}

Algeria has used different types of contract: concessions agreements and production sharing agreements. In 1986, Algeria enacted a new hydrocarbon law that allowed greater access to foreign capital through production sharing agreement, joint ventures and risk service contracts and relaxed the fiscal terms by reducing the royalty and income tax rates. The new law met fierce opposition by the Parliament and was passed only after introducing a number of amendments to the law. Among these amendments, the 1986 hydrocarbon law required that a foreign company's share does not exceed $49 \%$ and ruled out partnerships in projects in which hydrocarbon deposits have been discovered prior to the passing of the law. The latter meant that foreign investment in redeveloping existing fields and investment in EOR projects were not allowed. Foreign oil companies did not respond very positively to the 1986 hydrocarbon law (IEA, 1996). This pushed the government to makes changes to the existing 1986 Hydrocarbon law. After lengthy discussions, the Parliament approved 14 amendments in 1991 which were attached to the 1986 hydrocarbon law. These amendments allowed companies to gain equity interest; treated oil and gas on the same basis; allowed for international arbitration in cases of dispute; and relaxed further the fiscal terms (Aissaoui, 2001, IEA, 1996). The 1991 amendments attracted foreign interest and led to the award of large number of oil exploration contracts which helped boost exploration and development activity. The political turmoil that plagued the country in the early 1990s did not stop the growing interest in Algeria.

In March 2005, the parliament passed a hydrocarbon reform bill aimed at encouraging foreign oil companies to invest and operate in areas which state-owned Sonatrach previously dominated. The 2005 hydrocarbon law had many distinguishing features. It created new independent with supervisory and regulatory institutions, namely Alnaft (Agence Nationale pour la Valorisation des Resources en Hydrocarbures) responsible for organising licensing rounds and the award of contracts and the Hydrocarbon Regulatory Authority responsible for overseeing technical matters such as health and safety regulations and access for storage facilities and pipelines. Second, the new hydrocarbon law shifted away from the production sharing mechanism. The new exploration contract is a regular tax and royalty agreement. The foreign oil company has to pay its share of taxes directly through a monthly proportional royalty based on the location of the field and the level of hydrocarbon production and a monthly petroleum income tax based on a sliding scale, which increases with the cumulative value of hydrocarbons production. Another major change involved government participation where the 2005 Hydrocarbon law did not allocate any rate of participation to the State. The 2005 Hydrocarbon Law however was amended in 2006, leading to the introduction of a windfall tax of up to 50\% on profits when oil prices top $\$ 30$ per barrel. Furthermore, the new amendments required that the rate of participation of the national oil company be fixed at a minimum rate of $51 \%$ (EIA, 2007). This participation element kicks in after commercial discovery which means that all exploration risk is borne by the foreign contractor. The main elements of the new agreement are summarised in the table below. For many observers, the recent change in fiscal terms in Algeria are yet further evidence in the rise of the wave of oil nationalism all over the world. 
Table 4: Algerian Fiscal Terms

\begin{tabular}{|l|l|}
\hline & None \\
\hline Bonuses & Depends on area. Minimum is 12\%. \\
\hline Royalties & $\begin{array}{l}\text { Petroleum Income tax on monthly basis and varies from 30 } \\
\text { to } 70 \% \text { according to the value from the beginning of } \\
\text { exploitation of hydrocarbons. }\end{array}$ \\
\hline Windfall Tax & $\begin{array}{l}\text { Minimum: 5\%, Maximum: 50\% } \\
\text { A non-deductible tax on exceptional profit obtained by } \\
\text { foreign companies applies to portion of production reverting } \\
\text { to them if monthly arithmetic mean of Brent petroleum price } \\
\text { is greater than \$30. }\end{array}$ \\
\hline Participation & $\begin{array}{l}\text { The rate of participation of the national oil company is fixed } \\
\text { at minimum rate of 51\%. }\end{array}$ \\
\hline
\end{tabular}

Based on Hydrocarbon Law 05-07 of 28 April 2005 and Ordinance No. 06-10 of 30 July 2006 Amending and Supplementing Law No. 05-07 of 28 April 2005

The Algerian case illustrates two interesting points: frameworks produced in order to eliminate foreign influence decades ago have been turned into cooperative agreements since the mid 1980s, allowing de facto participation by foreign oil companies. However, in the face of local opposition, there are limits on how far the liberalisation of oil sector can go and when the balance of power of power shifted towards the government, reforms were stalled.

\section{Egypt: Mature area with Massive Foreign Interest}

For Egypt, the financial capital, management skills and technology brought in by foreign oil companies have always been vital for the development of its upstream oil sector. Consequently, over the years Egypt maintained a stable and clear legal and institutional framework for investment in the oil sector. It also offered relatively attractive fiscal terms and has been flexible to adjust the fiscal terms as output began to decline in the mid 1990s. This strategy paid off over the years. In the 1970s, rising oil prices and attractive fiscal terms paved the way for the entry of many foreign companies, including the return of some oil companies that left Egypt in the 1960s. As a result, exploration activity intensified which resulted in many oil finds in the Gulf of Suez. In 1976, Egypt became a net exporter of crude oil for the first time. Oil output continued to climb reaching 900,000 b/d in 1984.

Faced with a severe fiscal and debt crisis in the mid 1980s, Egypt embarked on a structural reform programme which affected many sectors, including the oil sector which was a key foreign currency earner. Specifically, Egypt attempted to increase the oil available for exports. However, the increase in domestic consumption and natural decline in major oilfields meant that this strategy was not effective. It is during this period when Egypt turned its attention to natural gas. This shift was caused by many factors including the rapid rise in the demand for natural gas and efforts to increase production of natural gas to make more oil available for exports. Although 
Egypt had considerable amounts of natural gas, Egyptian General Petroleum Corporation (EGPC) has done little to exploit its potential. To reverse this strategy, Egypt started making some changes in the concession agreements. Before the 1980s, all the gas discovered went automatically to EGPC. In 1981, a gas provision was introduced which gave companies gas rights, but these provisions did not provide enough incentive for oil companies to explore and develop gas reserves. In 1985, a Gas Clause was introduced in which gas was to be treated similar to oil in production sharing agreements. In 1988, Shell and EGPC signed the first Gas Clause which became the standard agreement for any future gas concessions. This and other subsequent changes in the terms of fiscal terms led to an increase in exploration and production of natural gas in the 1990s (EIA, 2007).

The active partnership with foreign oil companies continued in the 1990s. Exploration and drilling activity in the last two decades resulted in oil finds but these finds were rather small and have not been able to reverse the decline in oil production. Egypt's oil production peaked at 910,000 b/d in 1993 and since then has been in continual decline. To reverse this trend, Egypt continues to offer blocks through a series of exploration bid rounds carried by EGPC, EGAS and Ganope. During the period 2001 and 2006, Egypt offered more than 150 blocks to local and foreign companies. These rounds resulted in the award of exploration contracts to a wide range of players. According to the Egyptian Ministry of Petroleum website, there are around 29 foreign upstream operative companies in the energy sector. In addition to attracting super majors and large oil companies, small independent oil companies such as Apache have been able to make an inroad into Egypt especially in the Western Desert. Also in recent years, a number of Egyptian companies have entered the upstream sector though that not all these Egyptian companies are private.

Given Egypt's long term strategy of partnerships with foreign investors, it should come as no surprise the dominance of foreign oil companies in oil production. With the exception of few fields owned and operated by state-owned oil companies, oil production is dominated by joint ventures between EGPC and foreign companies. The table below shows that Egypt's main producing fields are operated by Gupco, Suco and Agip with the latter accounting for almost third of Egypt's total oil production. As can be seen from this table, Egypt's oil sector is mature with many of the most important producing fields such as Morgan and Belayim Marine being discovered in the 1960s. The main challenge for foreign oil companies since the mid 1980s, therefore, has been to arrest the decline rates of mature fields using EOR projects.

\subsection{Contracts and Fiscal Terms}

In 1956, Egypt established the General Petroleum Authority (renamed in 1962 to Egyptian General Petroleum Corporation (EGPC)) to safeguard Egypt's interests in the petroleum sector. Since that date, the EGPC has become a major player in Egypt's energy sector. But rather than doing it alone, EGPC entered into a series of joint ventures with foreign oil companies. In 1963, it entered in a joint venture with Standard Oil Company to form the Gulf Suez Petroleum Company (GUPCO) which made the major find, the Morgan field in 1965 in the Gulf of Suez. In the same year, it entered in a joint venture with Eni (which operates in Egypt through the International Egyptian Oil Company (IEOC)) to form Petrobel. Partnership with foreign oil companies accelerated through the 1970s but it took different form. Since 1973, EGPC 
abandoned its old-style joint ventures in which the national oil company used to bear part of the exploration risk cost in favour of contractual agreements based on production sharing. From 1973 onwards, Production Sharing Agreement (PSA) become the standard arrangement for foreign upstream activities and all existing joint ventures were converted to PSAs (Taverne, 2000).

Table 5: Egypt: Major Producing Fields and Operators

\begin{tabular}{|l|r|l|l|l|}
\hline Field Name & $\begin{array}{l}\text { Discovery } \\
\text { Date }\end{array}$ & Operator & $\begin{array}{l}\text { Number } \\
\text { of } \\
\text { Producing } \\
\text { Wells }\end{array}$ & $\begin{array}{l}\text { 2005 } \\
\text { Average } \\
\text { Production } \\
\text { (b/d) }\end{array}$ \\
\hline Ashrafi & 1990 & Agip & 11 & 13,500 \\
\hline $\begin{array}{l}\text { Belayim Marine, Belayim } \\
\text { Land }\end{array}$ & $\begin{array}{l}\text { 1961, } \\
1953\end{array}$ & Agip & 106 & 154,400 \\
\hline Meleiha & 1980 & Agip & 61 & 19,000 \\
\hline Port Fouad & 1982 & Agip & 7 & 15,800 \\
\hline Ras Qattara & 1993 & Agip & 7 & 12,200 \\
\hline Badri & 1981 & GUPCO & 37 & \\
\hline GS172 & 1988 & GUPCO & 10 & \\
\hline Hilal & 1982 & GUPCO & 15 & \\
\hline July & 1973 & GUPCO & 34 & \\
\hline Morgan & 1965 & GUPCO & 81 & \\
\hline October & 1978 & GUPCO & 49 & \\
\hline Ramadan & 1974 & GUPCO & 34 & \\
\hline Ras Budran & 1979 & SUCO & 13 & \\
\hline Ras Fanar & 1980 & SUCO & 10 & \\
\hline Zeit Bay & 1980 & SUCO & 32 & \\
\hline Badr El Din 1 & 1981 & BAPTECO & 11 & \\
\hline Badr El Din 3 & 1983 & BAPTECO & 13 & \\
\hline Sinai & 1987 & Petrobel & 4 & \\
\hline Qarun & 1995 & Qarun & 25 & \\
\hline Other & & & 707 & \\
\hline Total & & & $\mathbf{1 2 6 7}$ & $\mathbf{6 9 5 , 0 0 0}$ \\
\hline & & & & \\
\hline
\end{tabular}

Source: Oil and Gas Journal Data Book, 2007Edition. 
Egypt was fast to adopt the PSA model developed in Indonesia. However, the Egyptian authorities retained some of the features of participation in concession agreements used before the 1970s. The end result was a model oil agreement that contains a mixture of state participation and PSA elements (Taverne, 2000). In terms of the features of the old style agreement, the Egyptian government kept the concession system but concessions are given exclusively to EGPC. When entering into an agreement with a foreign oil company, in effect the Egyptian government is entering into an agreement with EGPC in which it provides it with exclusive concession to explore and develop a certain area and another one with a foreign oil company that acts as a contractor and agrees to undertake its obligations with respect to the exploration, development and production of petroleum. As concession holder, EGPC pays royalty of 10\% of well-head output to the government. Royalty payment "shall not be the obligation of contractor". This system is probably followed so that the contractor does not have any right, title, interest or estate in petroleum produced from any exploration block or development lease.

When a commercial discovery is made and the parties agree to develop the field, the exploration licence is converted into a development lease. At this stage, the EGPC and foreign contractor usually form a joint stock company referred to as an operating company. Both the EGPC and partner pay own one half of the capital stock of the operating company. This newly created company acts as the agency through which EGPC and the foreign partner carry out and conduct their development operations. The operating company keeps account of all costs, expenses and expenditures. All accounts have to be approved by a Board of Directors consisting of eight members (four designated by EGPC and four by foreign operator). The contractor/operator company is liable to pay income tax but this tax is paid by the EGPC on the behalf of the contractor.

The PSA features of oil contracts in Egypt are reflected in the use of cost oil and profit oil to divide the rent between EGPC and the contractor. The contractor is entitled to recover his exploration and development expenditures plus operating costs from cost oil. The remaining oil (i.e. profit oil) would be divided between the EGPC and the foreign investor based on some agreed profit ratio. The law was amended in 1994 to make all terms of the agreement such as production shares, cost oil and bonuses subject to negotiations and to address some environmental concerns. In 2002/3, the agreement was further amended requiring contractors to give preference to local qualified personnel if appropriate and earmark a special budget for training local employees (Alami, 2006). As can be seen from the table below, the model agreement is quite flexible allowing parties to negotiate the cost recovery rates and profits shares depending on the potential of the oil field and market conditions. The main elements of this agreement are summarised in Table 6 below. 
Table 6: Egypt's Production Sharing Agreement and Fiscal Terms

\begin{tabular}{|ll|}
\hline Bonuses: & $\begin{array}{l}\text { Signature Bonus, development bonuses, production } \\
\text { bonuses, contract extension bonuses }\end{array}$ \\
\hline Rentals and fees: & Yes; paid by the operating company \\
\hline Royalties: & 10\% of well-head output; paid by the EGPC. \\
\hline Income tax: & Paid on behalf of contractor by EGPC. \\
\hline & $\begin{array}{l}\text { 20\% for exploration \& development costs; operation costs } \\
\text { totally amortisable. }\end{array}$ \\
\hline Post oil: & Varies according to output and field; negotiable \\
\hline Negotiability: & All terms negotiable \\
\hline Stability: & All terms in contract \\
\hline
\end{tabular}

Notes:

(1) A production company must be established within a month of commercial discovery. It is governed by the bylaws of shareholders between EGPC and the contractors.

(2) At commercial discovery, the contractor is awarded a development lease of up to 20 years. EGPC must approve any re-selling of licences awarded.

(3) Egyptian legal provisions for environmental protection apply to all operations.

Source: EGPC Model Agreement, EGPC Website: http://www.egpc.com.eg/

\section{Sudan: the Land of Asian NOCs}

The development of Sudan's oil sector did not follow a smooth path and was hampered by adverse political events plaguing the country. Due to the long civil war and the pressure of sanctions and powerful pressure groups, Western petroleum companies were forced to exit Sudan. This void was filled by Asian national oil companies mainly from China, Malaysia and India which currently dominate the Sudanese oil sector. In 1975, the government of Sudan granted Chevron a concession area of $516,000 \mathrm{~km}^{2}$ in the South of the country. Chevron started geological and geophysical surveys in 1976 and in 1979 it made its first oil discovery. Chevron made two significant finds in the early 1980s with the discovery of the Unity oilfield in 1980 and Heglig field in 1982. Chevron estimated that the two fields to contain total oil reserves of 593 million barrels. After a heavy investment in Sudan estimated at $\$ 1$ billion (in 70/80s dollars), Chevron was forced to suspend its operation in 1984 and completely exited the country in 1992. Chevron's departure was due to a number of factors including the eruption of the civil war, continuous attacks on oil installation and threats to expatriate employees. The seizure of power by the Islamist government in 1989 did not help as the new financially-starved government gave Chevron the choice either to develop the field or to sell the concession. Chevron opted for the latter and sold its concession to an unknown Sudanese oil company ConCorp. Concorp sold its concession to a private Canadian oil company, State Petroleum Corporation, which in 1994 sold it concession to a publicly traded Canadian company, Arakis Energy Corporation (Arakis), a small Canadian exploration company. Arakis was not able to raise the necessary finance to construct the pipeline needed to link its oil fields to Port Sudan on the Red Sea. Araskis decided to seek new partners and in 1996 it sold 75\% of its share to China National Petroleum Corporation (CNPC), Petroliam Nasional Berhad (Petronas), and the national Sudanese oil company (Sudapet) and formed a new consortium, the Greater Nile Petroleum Operating Company (GNPOC) with Arakis acting as the operator. In 1998, Arakis sold its share to a fellow 
Canadian oil company, Talisman Energy, which assumed the role of an operator. Oil assets in Sudan were vital for Talisman's global energy portfolio, but after four years of engagement it decided to sell out its interest to India's Oil and Natural Gas Corporation Limited (ONGC). Talisman's departure was caused in part by outbreaks of violence, military attacks on oil installations and pipelines and in part by pressure from media and human right organizations that linked violence to Talisman's activities in Sudan.

Although oil was discovered in Sudan in the mid 1970s, production did not start until 1999. Since 1999, Sudan made important strides in developing its hydrocarbon potential and production has risen steadily increasing from around 50,000 b/d in 1999 to around 400,000 b/d in 2006 and over 550,000 b/d in 2007. Most of this production is accounted for by CNPC as shown in Table below. In addition to these producing oilfields, a large number of blocks are currently being explored by Asian NOCs (See Appendix IV).

Table 7: Oil Production by Block/Operator, 2007

\begin{tabular}{|c|c|c|c|}
\hline $\begin{array}{l}\text { BLOCK } \\
\text { NO. }\end{array}$ & Operator & Owner & Production b/d \\
\hline $1,2,4$ & GNPOC & $\begin{array}{c}\text { CNPC (40\%), Petronas (30\%), ONGC } \\
(25 \%), \text { Sudapet (5\%) }\end{array}$ & 285,000 \\
\hline 3,7 & Petrodar & $\begin{array}{l}\text { CNPC (41\%), Petronas (40\%), SINOPEC } \\
\text { (6\%), Al-Thani (5\%), Sudapet (8\%) }\end{array}$ & $160,000-180,000$ \\
\hline $5 a$ & $\begin{array}{l}\text { White Nile } \\
\text { Petroleum } \\
\text { Company }\end{array}$ & $\begin{array}{l}\text { Petronas (68\%), ONGC (24\%); Sudapet } \\
\text { (7\%) }\end{array}$ & 80,000 \\
\hline $5 b$ & Petronas & $\begin{array}{c}\text { Petronas (41\%), Lundin (24.5\%), ONGC } \\
\text { (24.5\%), Sudapet (10\%) }\end{array}$ & - \\
\hline 6 & CNPC & CNPC (92\%); Sudapet (8\%) & 40,000 \\
\hline 8 & & $\begin{array}{c}\text { Petronas (77\%), Sudapet (15\%); } \\
\text { Hitch (8\%) }\end{array}$ & - \\
\hline 9 & & Zafer (84\%); Sudapet (16\%) & - \\
\hline 15 & $\begin{array}{l}\text { CNPC (35\%) and } \\
\text { Petronas (65\%) }\end{array}$ & CNPC (35\%) and Petronas (65\%) & - \\
\hline & & & $565,000-585,000$ \\
\hline
\end{tabular}

Source: MEES, Vol. XLIX NO 16 
Given the uncertainty regarding the unity of Sudan post-2011, establishing whether a field lies within the Southern or Northern borders is important for future investment. A few of Sudan's oil producing fields are located in the disputed border area between the South and the North and this has caused a major disagreement between the parties. For instance, disagreement has risen regarding the location of the Heglig field in Block 2. While the NCP stresses that field is located in the Northern area, the SPLM claims that this area is part of the South and that the northern government has been moving the border gradually southwards to lay claim to oil found in the south. Figure 3 below shows oil production by producing block for the year 2006 divided between South and North according to the classification used by the Bank of Sudan. As can be seen from this figure, the bulk of oil production originates from fields located in the Southern part of the country.

Figure 3: Percentage of Production by Producing Block in 2006

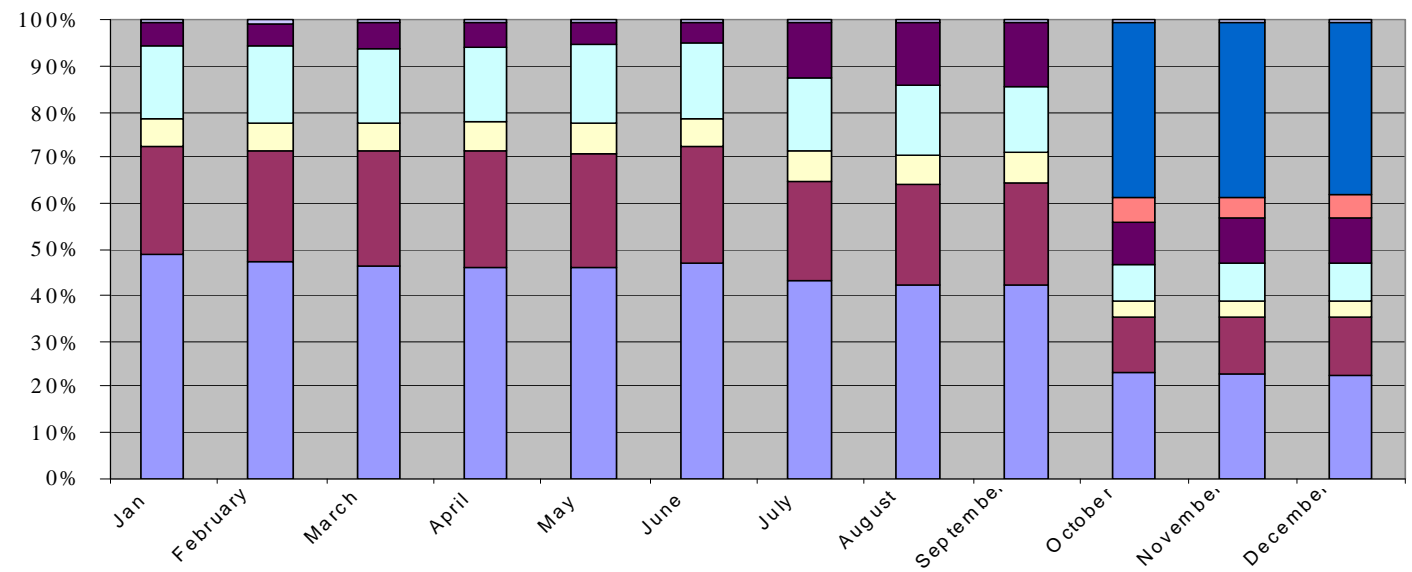

$\square$ Block 1 A $\square$ Block 1 B $\square$ Block 2 A $\square$ Block 2 B $\square$ Block $4 \square$ Block 5 A $\square$ Blocks $3,7 \square$ Block 6

Notes: Block 1: 100\% from South; Block 2: 100\% from North; Block 4: 100\% from North; Block 5A: 100\% from South; Blocks 3\&7: 100\% from South; Block 6: 100\% from North

Source: Central Bank of Sudan, MEES

\subsection{Oil Contracts and Fiscal Terms}

Oil companies' investment in the Sudanese oil sector is organised on the basis of exploration and production sharing agreements. The basic elements of the production sharing agreement used in Sudan are summarised in Table 5. The table describes the typical company take from $\$ 100$ million of gross revenues from a 100,000 b/d field. As can be seen from this table, the cost oil is set at $40 \%$ and profit oil is shared on the basis of 20/80. According to the table below, a company's total take (cost oil plus profit oil) is $27 \%$ of gross revenues which is considered quite attractive and comparable to other small oil producers such as Egypt and Yemen. 
Table 8: Typical Company Take in Sudan from US\$ 100 million of Gross Revenues

\begin{tabular}{|l|l|}
\hline Gross Revenue & 100 \\
\hline Cost Oil Limit & 40 \\
\hline Company Cost Recovery & 15 \\
\hline Excess Cost Oil to Government & 25 \\
\hline Profit Oil Pool & 60 \\
\hline Company \% Profit Oil (20\%) & 12 \\
\hline Government \% Profit Oil (80\%) & 48 \\
\hline Total Company Take & 27 \\
\hline Marginal Government Take & 73 \\
\hline
\end{tabular}

Source: European Coalition on Oil in Sudan (2006), “Oil and the Future of Sudan”, Conference Report, 1-2 November 2006, Juba, Southern Sudan

Despite the relative attractiveness of the fiscal terms, the risks engulfing the oil sector remain very high. Given its dominance in the Sudanese economy, the oil sector has become the subject of continuous political dispute resulting in conflicting visions and uncertainties about the country's oil policy. The recent dispute surrounding the exploration Block B (the largest concession in the South of the country) underscores some of these uncertainties. Until recently, there have been conflicting claims about the ownership of Block B between a consortium led by Total and a UK-based firm called White Nile. Total followed Chevron into Sudan in the 1980s and acquired equity in Block B. The Sudanese authorities continued to renew the license for Block B for many years despite its force majeure status due to the war. White Nile was granted a concession to explore the block by Government of Southern Sudan in 2005. The overlapping of authorities caused a dispute between the two companies which ended up in a British High Court. The ownership of Block 5B was also contested on similar grounds. Ascom, a Moldovan oil firm, was granted exploration rights by the GOSS in June 2005. A consortium led by Petronas and its partners had already signed an exploration contract for the same block with the Northern government in 2001. In 2007, the NPC ruled that Ascom's concession in Southern Sudan is invalid.

The risk that the existing fiscal regime in Sudan may change also remains high. There is still high uncertainty surrounding the future of Sudan as one country. With the majority of people in the South desiring independence from the North, there is a high probability a new state will be created on the Southern area in 2011. Central government's delay in implementing core elements of the CPA, disagreements on how to share oil revenues, the deep divisions within SPLM on whether to support unity full heartedly and occasional fights in Abyei are not helping the case for unity. Unless there is a dramatic transformation in factional politics, the possibility of partition should be taken very seriously. If the Southerners decide against unity and opt for independence, there is a big chance that the oil sector would experience dramatic reorganisation. The newly 
created state may decide to alter existing concessions, to revise the fiscal terms and to introduce new laws and contracts. Given the Southern view that existing companies operating in Sudan contributed to the strengthening of the ruling party, the newly independent state may prefer to deal with private western firms rather than Asian national oil companies. Such uncertainty implies that oil companies would be reluctant to make long-term investment plans in the Southern part of the country.

\section{Assessment and Evaluation}

The above discussion shows that North Africa provides a rich framework for analysing many key issues related to the oil sector. In this section, we draw some lessons concerning the relationship between domestic governments and foreign oil companies and the evolution of the fiscal regime over time and across countries. Although these are drawn in the context of North Africa countries, some lessons may have wider relevance.

\section{1 National Oil Companies and Reliance on Foreign Oil Companies}

NOCs are not of uniform quality and institutional nature. On the one hand, the NOCs of Algeria and Libya have played an operational role alone or side to side with foreign oil companies and have gained greater confidence in their capacity to develop their own resources. With the support of service companies they could tackle tasks that were not feasible in the past. At the other end of the spectrum, the NOC in Sudan has failed so far to acquire the necessary technology and management skills and has not operated independently of foreign oil companies. A recent survey published by MEED reflects the significant qualitative differences in administrative quality, independence, and profitability that distinguish these companies. While Algeria's Sonatrach is considered as relatively well-managed with a high score on commercial performance and human resources and medium scores on technology, Egypt and Libya have NOCs that display only a profile at the middle of the scale. Sudan was not included in the survey, but on all the points, it would have scored quite low. Given their diversity, it is important for foreign oil companies to fully understand the role and the capability of the NOC in each country and show clearly in which areas foreign oil companies can contribute to NOC's development.

Given the differences in NOC's capabilities in different areas, the view that there will be less reliance on foreign oil companies cannot be easily generalised in the North African context. For heavy dependents such as Sudan and Egypt to a lesser extent, the financial capital, management skills and technology brought in by foreign oil companies are vital for their upstream sectors. In Sudan and Egypt, the need for foreign oil companies' financial resources is felt particularly in the areas of exploration and development. The funds allocated for E\&D in these countries are too slim for the amounts required and risks involved. The NOCs in Egypt and Sudan also lack the technological capability to deal with mature fields. 
Table 9:

\begin{tabular}{|l|l|l|l|}
\hline & $\begin{array}{l}\text { Sonatrach } \\
\text { (Algeria) }\end{array}$ & NOC (Libya) & EGPC (Egypt) \\
\hline Commercial Performance & 8 & 6 & 6 \\
\hline Production & 6 & 5 & 6 \\
\hline Reserves Replacement & 4 & 4 & 5 \\
\hline Downstream Investment & 4 & 2 & 4 \\
\hline Partnership & 5 & 6 & 7 \\
\hline Technology & 6 & 2 & 4 \\
\hline Overseas Investment & 8 & 6 & 0 \\
\hline Independence & 7 & 6 & 5 \\
\hline Environment & 7 & 4 & 4 \\
\hline Human Resources & 8 & 5 & 4 \\
\hline Total & $\mathbf{6 3}$ & $\mathbf{4 6}$ & $\mathbf{4 5}$ \\
\hline
\end{tabular}

Source: MEED, 18 May 2007, “The Age of Nationals” by Richard Nied, p. 4f.

For oil-rich NOCs of Libya and Algeria, the main task since nationalisation was to manage excess supply rather than growing capacity. These NOCs have little experience in dealing with large-scale capacity expansion projects. Even maintaining output capacity is now more expensive and more difficult as reservoirs age. Cost inflation from stronger pricing positions of key suppliers given the widespread surge in demand for their products and services implies that investment requirements will be greater than the initial estimates.

Furthermore, the maturity of producing basins will induce Sonatrach and Libyan NOC to develop a two-track exploration and production strategy. The first track of the proposed strategy refers to the opening of new areas for exploration. These projects are more risky and most North African governments seem to be not willing to commit capital for exploration purposes. This foreign capital allows recipient countries to front-load capital requirements and to spread risks, particularly when it comes to new ventures. This has provided many opportunities for foreign oil companies to gain greater access to reserves in North African region. The second track is to aim at improving the recovery factors of producing fields in order to reduce decline rates and increase reserves. This implies the application of new technology, more and better engineering, the adoption of best practice techniques, greater managerial discipline, rigorous economic analysis of alternatives and sustained efforts to reduce the costs of secondary and enhanced recovery projects. If Libya and Algeria are to realistically meet their targets of increasing 
production capacity in the coming years ahead, then they have to speed this second track. The challenges are not minor and the national oil companies are not well prepared for the task of designing and implementing enhanced oil recovery and improved reservoir management for ageing fields.

The country-specific discussion above show the diversity of foreign players in North African oil sectors (super majors, independents, national oil companies, private domestic companies). Interestingly, with the exception of Egypt, super majors are not dominant in the North African oil scene. It is often argued that for super majors, size and scale of investments projects are central to their investment decisions and that profitable projects can be turned down if they do not pass the materiality threshold of a company or if there is not enough potential for repeated investment opportunities so that the oil company can build a critical mass. The country experiences however suggest that access to large reserves is neither necessary nor sufficient motivation for super majors' investment in oil sector. Super majors are willing to enter in countries with mature basins and a low reserve base indicating that factors such as host country's attractive fiscal terms are equally important. In fact, it may be more attractive for foreign oil companies to exploit less prospective areas but which achieve the required rates of return. This explains the strong interest in mature producing areas such as Egypt which offers relatively attractive fiscal terms and clear legal and institutional framework for investment in the oil sector.

Independent oil companies have been acquiring an increasing role in these countries' oil sectors. North African producers have benefited from the changing strategies of independents, who are now seeking to grow via acquisitions abroad. These independents are willing to explore smaller areas with low hydrocarbon deposits, to pick up concession blocks abandoned by majors, and create 'niche' advantages. The technology brought in by these independents has played an important role in reviving the Egyptian and Algerian oil sectors. While super-majors have been active in Egypt, many of the more recent discoveries were led by companies such as Apache. Anadarko's expertise in mature basin management helped Anadrako establish itself as the leading operator in Algeria.

NOCs from China, Malaysia, Russia and India are also playing an increasing role in North Africa. These NOCs are eager to develop their international investment in search for new sources of supply. These companies do not generally seek as high a rate of return on their investments and are not driven by the objective of shareholder value maximization as other oil companies. Thus, they are likely to be flexible in negotiating contracts with NOCs and their governments. These may be willing to acquire and operate very small fields and take excessive risks. Furthermore, these NOCs may benefit from state to state connections and thus get better access on the basis of a more general agreement between the two states. In Sudan NOCs assumed dominant position due to sanctions and external pressures on private oil companies. In the rest of the North Africa countries, these newcomers have still to convince host countries that they have the necessary capabilities for the tasks to be undertaken. In the case of technologically sophisticated projects, this may be a hard challenge to meet. Given time, however, the newcomers will inevitably develop expertise and a range of capabilities and be able to pose a credible challenge. 
Finally, international sanctions have played an important in the way the oil sector has evolved and the type of players attracted to the oil sector. Unilateral and/or multilateral sanctions imposed on Sudan and Libya has adversely affected access as foreign oil companies had to weigh the benefits against the costs of entry. These sanctions undermined the country's potential by reducing investment and blocking technology transfer with adverse consequences on the productivity of producing fields. However, they did not inflict a fatal blow on these countries' oil sectors and in fact despite sanction, output continued to grow and oil companies continued to flock into these countries. The sanctions imposed on Sudan favoured the entry of Asian national oil companies which helped transform Sudan into an oil exporter. In Libya, the departure of US companies was partly compensated by increasing role for European companies. Furthermore, the Libyan NOC was able to take control over the deserted fields with the help of service companies. The impact of sanction however was felt hard on the exploration and development activities and technology transfer to the NOC.

\subsection{Oil Contracts, Fiscal Terms and Investment}

Regarding the fiscal terms, it is possible to draw the following lessons. First, the cases of Libya (and Algeria to a lesser extent) show that access to rich oil areas does not necessarily ensure that oil companies would achieve a high rate of return. Thus, it is often the case that the upstream terms acceptable to host countries with high quality reserves, low production costs, no exploration risk and with a capable national oil company do not enable oil companies to achieve their required rate of return. In other words, while access to large and high quality reserves is an important factor for venturing into a certain country, high quality reserves do not necessarily produce the required rate of return required by the company's shareholders.

Second, contrary to what one would expect, low oil prices can induce foreign investment in certain countries. This is clear in the case of Algeria where most of the exploration and development activity took place in the mid 1980s and 1990s when oil prices were relatively low. This paradox can be explained by the fact that an environment of low oil prices puts strains on the budgets of national oil companies with adverse consequences on exploration, development or even production. This induces countries to open their sector to foreign investment and amend their laws and contract terms to make it more attractive for foreign oil companies. Oil companies often respond to the improved fiscal incentives even in low price environment. They considered it as an opportunity to establish a first mover advantage in previously closed areas.

Third, the situation of a producer country at the beginning of its career is distinguished by severe power and information asymmetries. Contracts and fiscal regimes are likely to be sub-optimal from the local partners' point of view. At the beginning of the oil era, this led to skewed contracts that left domestic governments with a very moderate stake in the continuity of the system. As markets tightened and balance of power shifted towards producers in the 1970s, Libya and Egypt restructured the traditional concession system while maintaining foreign presence but achieved more favourable fiscal arrangements in terms of higher royalties, taxes and bonus payments and more restrictive provisions on foreign companies’ operations.

While the 1970s with their oil shocks brought the first major modification in the balance of power towards government, the terms and conditions demanded by North African producers 
such as Algeria and Libya have been hardening again more recently. These trends will be further reinforced by growing long-term demand for oil and gas, and by decreasing opportunities open to international oil companies. In Algeria, this led to the introduction of a windfall profit tax when oil price is above \$30. This has already strained relations between Sonatrach and its partners. One such partner is US's Anadarko, the largest foreign operator in the Algerian oil sector and most hardly hit by the recent change in the hydrocarbon law. Anadarko considered that that the collection of the exceptional profits tax is not lawful arguing that its contract "provides fiscal stability through several of its provisions that require Sonatrach to pay all taxes and royalties". The parties reached a stalemate on whether Sonatrach has the right to negotiate on the basis of the new hydrocarbon law and in October 2007, agreed to be subject to non-binding conciliation process. So far, the conciliation process did not produce any outcome and the two parties still are locked in the dispute which if not resolved amicably could ultimately end in international arbitration. This dispute is already affecting the development of some key projects. One such project is the El-Merk in Block 208, discovered by the Sonatrach-Anadarko Association. The development of El-Merk filed, which upon completion is expected to bring 108,000 barrels of oil per day, 55,000 barrels of condensate per day and 75,000 barrels of LPG per day, has been delayed until 2011, three years later than originally planned. The Algerian Minister Chakib Khelil insists that the delay is not related to change in the law. Instead, he claims that the project has proven to be more challenging than originally anticipated and that the Ministry wanted to get more Algerian firms involved so as to increase local content. Regardless of the cause, Algeria's has decided to scrap its ambitious plans to reach production of $2 \mathrm{mb} / \mathrm{d}$ by 2010.

The impact of the high oil prices environment on fiscal terms was also reflected in the competitive bidding process in Libya which resulted in government obtaining a high share of the oil produced. The impact of such hardened terms can have its impact on investment through many venues. First, the strict fiscal terms means that making some the projects profitable is very challenging. Lower oil prices, unexpected escalation of costs, and/or failing to make big discoveries may render many of the projects unattractive for the contractor. In such cases, the oil company would most want to renegotiate existing contracts. These renegotiations can prove costly and may cause serious delays in implementing some of the marginal projects. Second, there is always the risk that harsh terms may dissuade firms from participating in future rounds. In the latest gas bid round last year, 35 companies were pre-selected to bid for 12 exploration areas (41 blocks) of prospective gas areas which cover more than $700,000 \mathrm{~km}^{2}$. This round attracted big players such as Shell, Gazprom, and Sonatrach but the turnout was rather low. Only 13 companies put in bids and so far NOC only awarded five of the 12 exploration rounds. This lack of interest may be due to lack of the gas potential of the blocks in offer, but also may be related to the unattractive fiscal terms on offer. Unattractive fiscal terms may dissuade firms from participating in DPSA rounds when NOC decides to go ahead with them.

In the next few years, the key issue in Libya and Algeria would not be one of access to reserves but whether the fiscal terms provided by their governments will be acceptable to foreign oil companies. On the other hand, Egypt and Sudan did not attempt to introduce major changes to their fiscal terms in recent years. This may indicate that contract amendments and fiscal term revision is more likely to affect countries with large reserves, but less so in mature areas or countries with limited unknown potential or large uncertainties such as Sudan. 
Finally, the discussion of the trajectories of individual countries shows that for many governments, the form of the contract matters. For instance, all North African governments with the exception of Sudan insist on some sort of state participation through joint ventures or joint operating companies. The choice of this structure may be attributed to many factors. In terms of government take, the government wishes to share the upside potential in any project. However, this can be easily achieved by modifying the PSA agreement to incorporate a sliding scale or export taxes. There may be other factors that motivate this choice. One such factor is that the national oil company would like to participate directly in the daily management of its oil fields rather than leaving it entirely to the foreign operator. Another factor is related to technology transfer. Joint ventures are usually perceived as the most suitable vehicle for technology transfer. The enhancement of local labour skills is also cited as one factor to opt for joint ventures. In countries which insist that the NOC owns a substantial or majority equity ownership in the venture, this requirement may be motivated by nationalistic sentiment. Having the NOC as a partner in every venture seems to be politically attractive and is a way that the government can portray itself as protecting the national wealth.

\section{Conclusions}

This paper focuses on the oil sectors of Algeria, Libya, Egypt and Sudan. We review the oil contracts and fiscal terms used by North African governments and the evolution of foreign oil companies' involvement in the oil sectors of these countries. Although the relationship between foreign oil companies and the governments of North Africa has witnessed major transformations over the years and has taken different shapes across countries depending on country-specific factors, there are some important similarities with regards to the importance of foreign investment. These countries' oil sectors are still heavily reliant on foreign oil companies and this reliance is likely to increase further if these countries are to meet their ambitious expansion plans. Due to variety of reasons, North African countries have encouraged foreign investment in the oil sector by modifying the hydrocarbon law and relaxing the fiscal terms on offer. In response, oil companies have invested heavily in exploration and development and contributed to the growth of their oil sectors. The recent rise in oil prices and the limited opportunities available elsewhere meant that oil companies had to deal with more confident and assertive governments that are demanding a higher stake of the oil rent. The effectiveness in which governments and foreign oil companies adjust to this new reality will determine the extent and the pace of the future development of these countries' oil sectors. 


\section{References}

The Economist, 2007 Energy and Nationalism, Mar $8^{\text {th }}$.

Aissaoui, A. (2001), Algeria: The Political Economy of Oil and Gas. Oxford: Oxford Institute for Energy Studies.

Aït-Laoussine, N. (1999), “The Opening of the OPEC Upstream to Foreign Investors: The case of Algeria”, MEES 42 (19), 10 May, pp.D1-D5.

Bindemann, K. (1999), Production Sharing Agreements: An Economic Analysis. OIES WPM 25, Oxford: Oxford Institute for EnergyStudies.

Daniel Johnston, “Impressive Libya Licensing Round Contained Tough Terms, No Surprises”, Oil\&Gas Journal April 18, 2005

Gurney, J. (1996), Libya: The Political Economy of Oil. Oxford: Oxford Institute for Energy Studies.

International Energy Agency (1996), North Africa Oil and Gas. Paris: IEA.

Seymour, I., 1980. OPEC: Instrument of Change. London: Macmillan.

Richard Nied, “The Age of Nationals”, MEED, 18 May 2007, p. 4f.

Energy Information Administration (2007), Country Information: Algeria.

Energy Information Administration (2007), Country Information: Egypt.

European Coalition on Oil in Sudan (2006), “Oil and the Future of Sudan”, Conference Report, 1-2 November 2006, Juba, Southern Sudan.

Patey, L. (2006), A Complex Reality: The Strategic Behaviour of Multinational Oil Corporations and the New Wars in Sudan, DIIS Report, The Danish Institute for International Studies, March.

International Crisis Group (2008) "Sudan's Comprehensive Peace Agreement: Beyond the Crisis”, Policy Briefing No.50, ICG: Nairobi/Brussels.

International Crisis Group (2006). 'Sudan’s Comprehensive Peace Agreement: the long road ahead.’ ICG Africa Report No. 106). Nairobi/Brussels: ICG.

International Crisis Group (2005). 'The Khartoum-SPLM Agreement: Sudan’s Uncertain Peace” ICG Africa Report No. 96. Nairobi/Brussels: ICG.

Human Rights Watch (2003). 'Sudan, oil and human rights.' New York: Human Rights Watch.

Richards A. and J. Waterbury (1996), A Political Economy of the Middle East, State: Class and Economic Development, $2^{\text {nd }}$ edition, Boulder Colorado: Westview. 
Taverne, B.G. (2000) Petroleum, Industry and Governments: An Introduction to Petroleum Regulation, Economics and Government Policies. Kluwer Law International.

Skeet, OPEC: Twenty-Five Years of Price and Politics. (Cambridge: Cambridge University Press, 1988).

Mabro, R. (2007) Oil Nationalism, the Oil Industry and Energy Security Concerns. Real Instituto Elcano.

Otman, W. (2007), “Appraising the Libyan Petroleum Agreements: A Comparative analysis of Risk Factors \& an Evaluation of their Effectiveness”, Oil, Gas \& Energy Law Intelligence, Vol 5, Issue 4. 


\section{Appendix I: Licensing Rounds in Libya}

The new licensing rounds have generated a lot of foreign interest. In the first-round of bids, 104 offers from 56 companies were made for 15 areas (See Table in Appendix). Competition for the offered blocks was intense as reflected in the large number of bids for some of the blocks (fifteen bids were made for the offshore area 54 and area 106 in the Sirte basin). The first round of licensing was concluded in 2005 and resulted in the award of 15 areas with total area of 126,639 $\mathrm{km}^{2}$ with a total work programme commitment of US\$299 million. Encouraged by the success of the first round, the NOC announced a second bidding round in May 2005 offering 44 blocks. 51 companies took participation in the bidding process. In first quarter of 2006, the Libyan government awarded 40 of the 44 blocks with a total area of $94,080 \mathrm{~km}^{2}$. The oil companies' agreed to a total work programme of US\$482 million which include drilling 36 exploratory wells and 2D and 3D seismic survey. The second license round was dominated by European and Asian companies with a strong entry for Japanese oil companies. In August 2006, the Libyan authorities embarked on a third international bidding round for 14 areas (41 blocks). Seven licenses were first awarded on 20 December 2006 followed by three additional awards for areas that only received single bids. The oil companies' agreed to a total work programme of \$951 million. The third round saw a strong entry of Russian firms Gazprom and Tafneft. 
Table 1: Awards of the First Round of Licensing

\begin{tabular}{|c|c|c|c|c|c|c|c|}
\hline Basin & $\begin{array}{l}\text { Contract } \\
\text { Area }\end{array}$ & Blocks & Company & $\begin{array}{l}\text { Available } \\
\text { Open } \\
\text { Acreage } \\
\end{array}$ & No of Bids & $\begin{array}{l}\text { Operator } \\
\text { Share (\%) }\end{array}$ & $\begin{array}{l}\text { Bonus (\$ } \\
\text { millions) }\end{array}$ \\
\hline Sirte & 106 & 4 & $\begin{array}{l}\text { Oxy 90, Liwa } \\
10\end{array}$ & 6520 & 15 & 12.4 & 25.6 \\
\hline Murzuq & 131 & 4 & $\begin{array}{l}\text { Oxy 90, Liwa } \\
10\end{array}$ & 10381 & 10 & 13.3 & 25.6 \\
\hline Sirte & 124 & 3 & $\begin{array}{l}\text { Oxy 90, Liwa } \\
10\end{array}$ & 6113 & 4 & 10.8 & 15.3 \\
\hline Murzuq & 163 & 4 & $\begin{array}{l}\text { Oxy 90, Liwa } \\
10\end{array}$ & 11236 & 9 & 15.9 & 15.3 \\
\hline Cyrenaica & 59 & 2 & $\begin{array}{l}\text { Oxy 90, Liwa } \\
10\end{array}$ & 5298 & 1 & 38.9 & 1.1 \\
\hline Offshore & 36 & 4 & $\begin{array}{l}\text { Woodside 55, } \\
\text { Oxy 35, Liwa } \\
10\end{array}$ & 10414 & 7 & 17.4 & 16 \\
\hline Offshore & 52 & 4 & $\begin{array}{l}\text { Woodside 55, } \\
\text { Oxy 35, Liwa } \\
10\end{array}$ & 6182 & 6 & 17.9 & 10.05 \\
\hline Offshore & 53 & 4 & $\begin{array}{l}\text { Woodside 55, } \\
\text { Oxy 35, Liwa } \\
10\end{array}$ & 8047 & 8 & 19.8 & 8.12 \\
\hline Offshore & 35 & 4 & $\begin{array}{l}\text { Woodside 55, } \\
\text { Oxy 35, Liwa } \\
10\end{array}$ & 9070 & 3 & 10.4 & 5.21 \\
\hline Offshore & 54 & 4 & $\begin{array}{l}\text { Amerada } \\
\text { Hess }\end{array}$ & 9769 & 15 & 12.4 & 6.18 \\
\hline Murzuq & 177 & 4 & $\begin{array}{l}\text { Chevron } \\
\text { Texaco } 100\end{array}$ & 11317 & 6 & 12.8 & 0.6 \\
\hline Sirte & 86 & 4 & $\begin{array}{l}\text { Oil India 50, } \\
\text { Indian Oil 50 }\end{array}$ & 7078 & 5 & 18.4 & 0 \\
\hline Offshore & 18 & 4 & $\begin{array}{l}\text { Petrobras } 70 \text {, } \\
\text { oil Serach } 30\end{array}$ & 10307 & 2 & 31.8 & 1 \\
\hline Ghadames & 65 & 2 & $\begin{array}{l}\text { Sonatrach } \\
100\end{array}$ & 4374 & 4 & 25 & 2 \\
\hline Ghadames & 47 & 4 & $\begin{array}{l}\text { Verenex 50, } \\
\text { MEDCO } 50\end{array}$ & 10531 & 9 & 13.7 & 0.25 \\
\hline
\end{tabular}

Source: MEES; Daniel Johnston, "Impressive Libya Licensing Round Contained Tough Terms, No Surprises", Oil\&Gas Journal April 18, 2005 
Table 2: Awards of the Second Round of Licensing

\begin{tabular}{|c|c|c|c|c|c|c|}
\hline Basin & $\begin{array}{l}\text { Contract } \\
\text { Area }\end{array}$ & $\begin{array}{l}\text { Block } \\
\text { No }\end{array}$ & Company & $\begin{array}{l}\text { Available } \\
\text { Open } \\
\text { Acreage }\end{array}$ & $\begin{array}{l}\text { Operator } \\
\text { Share } \\
(\%)\end{array}$ & $\begin{array}{l}\text { Bonus (\$ } \\
\text { millions) }\end{array}$ \\
\hline Sirte & 102 & 4 & $\begin{array}{l}\text { Oil India/Indian } \\
\text { Oil }\end{array}$ & 2,750 & 10.5 & 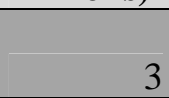 \\
\hline Sirte & 123 & 1,2 & BG & $\begin{array}{l}(2750, \\
2000)\end{array}$ & 10.9 & $7.5,7.5$ \\
\hline Sirte & 123 & 3 & Petramina & 2,030 & 8.8 & 7 \\
\hline Ghadames & 81 & 1 & ONGC Videsh & 1,900 & 11.8 & 6 \\
\hline Ghadames & 81 & 2 & Teikoku/Mitsubishi & 2,650 & 7.5 & 6 \\
\hline Ghadames & 82 & 3 & Teikoku/Mitsubishi & 2,500 & 7.5 & 6 \\
\hline Murzuq & 146 & 1 & Norsk Hydro & 2,444 & 7 & 7 \\
\hline Murzuq & 147 & 3,4 & Turkish petroleum & 2,270 & 9.7 & 7.262 \\
\hline Murzuq & 161 & 1 & Eni & 2,750 & 8.5 & 3.1 \\
\hline Murzuq & 161 & 2,4 & Eni & 3,900 & 7.9 & 4 \\
\hline Murzuq & 176 & 3 & Eni & 2,750 & 9.8 & 3.3 \\
\hline Murzuq & 176 & 4 & Japex & 2,750 & 6.8 & 3 \\
\hline Cyrenaica & 42 & 1,4 & Total/Inpex & 3,352 & 27.8 & 1.8 \\
\hline Cyrenaica & 94 & $1,2,3,4$ & Statoil & 10,000 & 24.9 & 2.95 \\
\hline Cyrenaica & 40 & 3,4 & $\begin{array}{l}\text { Japex, Nippon, } \\
\text { Mitsubishi }\end{array}$ & 4,540 & 8 & 1.7 \\
\hline Cyrenaica & 44 & $1,2,3,4$ & ExxonMobil & 10,290 & 28.5 & 1.5 \\
\hline Kufra & 171 & $1,2,3,4$ & Statoil/BG & 11,000 & 19.8 & 1 \\
\hline Kufra & 186 & $1,2,3,4$ & Eni & 8,400 & 15.4 & 1.1 \\
\hline Offshore & 2 & 1,2 & Nippon,Mitsubishi & 4,650 & 8 & 2.5 \\
\hline Offshore & 17 & 3 & Pertamina & 2,010 & 11.7 & 8 \\
\hline Offshore & 17 & 4 & CNPC & 2,535 & 28.5 & 6 \\
\hline
\end{tabular}

Source: MEES. 
Table 3: Awards of the Third Round of Licensing

\begin{tabular}{lrrrrr}
\hline \multicolumn{1}{c}{ Basin } & $\begin{array}{c}\text { Contract } \\
\text { Area }\end{array}$ & Blocks & Company & $\begin{array}{c}\text { Operator Share } \\
(\mathbf{\% )}\end{array}$ & $\begin{array}{c}\text { Bonus } \\
\text { Million) }\end{array}$ \\
\hline Offshore & 20 & 4 & Exxon Mobil & 22.30 & 10 \\
Offshore & 43 & 4 & ONGC & 28 & 10 \\
Murzuq & 113 & 2 & Inpex & 12.9 & 10 \\
Offshore & 19 & 4 & Gazprom & 10 & 10.1 \\
Ghadames & 82 & 1 & Tafneft & 10.4 & 10 \\
Ghadames & 98 & 2 & Tafneft & 10.4 & 10 \\
Sirte & 69 & 4 & Tafneft & 12 & 10 \\
Sirte & 137 & 2 & PetroCanada & 18 & 10 \\
Murzuq & 162 & 2 & CPC & 7.8 & 5 \\
Kufra & 201 & 4 & Wintershall & 13.5 & 3 \\
\hline
\end{tabular}

Source: MEES 


\section{Appendix II: Exploration and Production Blocks in Algeria}

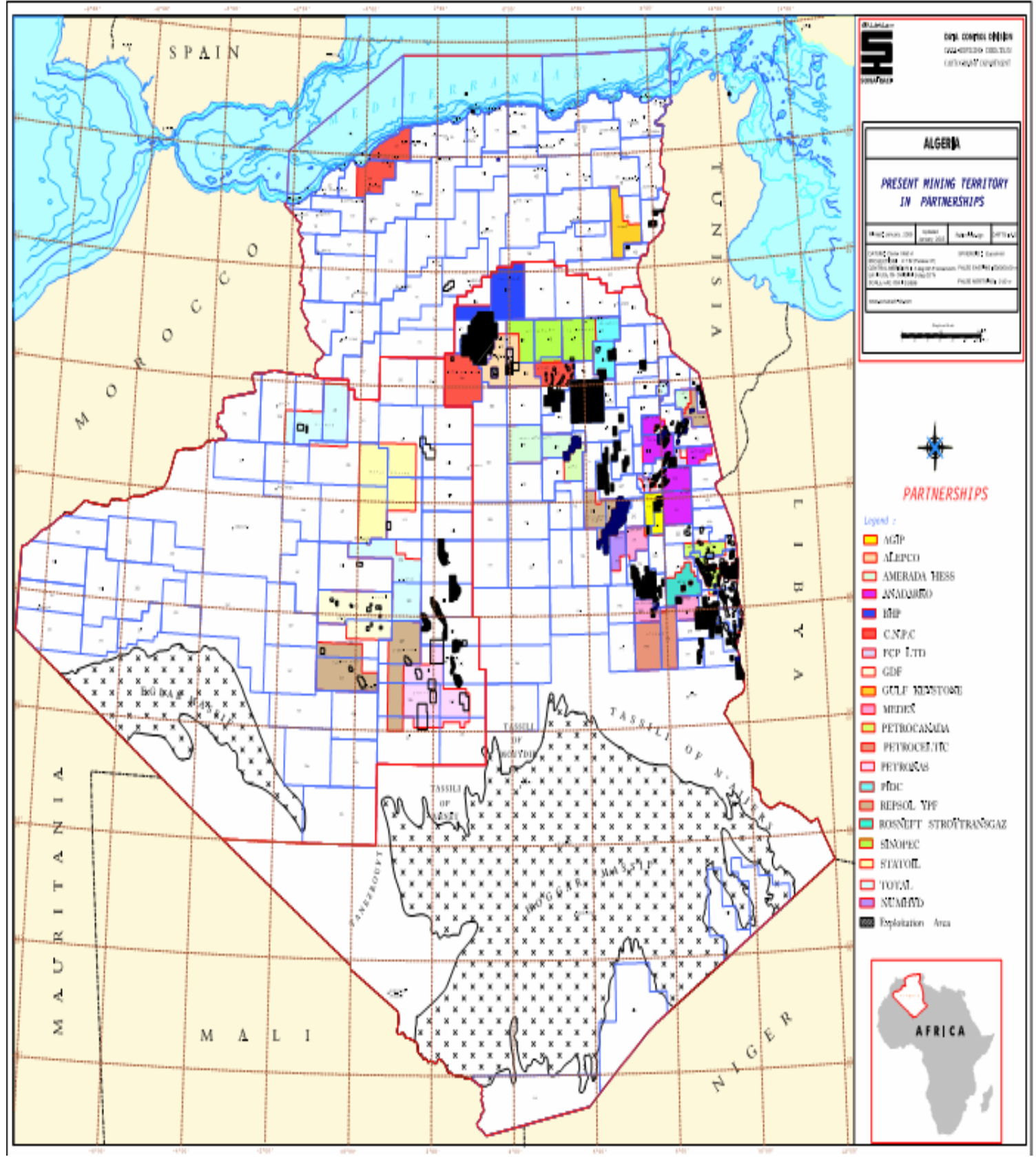




\section{Appendix III}

This appendix describes the concession agreement of 2002 between EGPC and Dover Investments Limited for an exploration area in East Wadi Araba Area, Gulf of Suez based on Barrows. The following are the main features:

1 The agreement stipulates that the government receives $10 \%$ of the total quantity of petroleum produced in kind or cash and that should be paid by the contractor.

2 In terms of bonus, the contractor shall pay EGPC a signature bonus of $\$ 300,000$; a production bonus of $\$ 2$ million when total average daily production reaches 25,000 ; a production bonus of $\$ 4$ million when total average daily production reaches 50,000. These bonuses are not recoverable by the contractor.

3 The exploration is granted for three years and could be renewed twice for 2-year periods. There is a minimum work programme where the contractor should spend a minimum of $\$ 3,500,000$ and the contractor should drill two wells. In case of applying for the two year extensions, the oil company should spend a minimum of $\$ 4,000,000$ in the first extension and $\$ 4,500,000$ in the second one.

4 Upon commercial discovery, the contractor is awarded a development lease and an operating company should be formed.

5 Cost oil is set at 30\% of all petroleum produced. Exploration expenditures are recoverable at a rate of $25 \%$ per year. Development expenditures are recoverable at $25 \%$ per annum. Operating expenses are recoverable in the tax year.

6 The remaining 70\% of profit oil is divided between EGPC and the contractor. The shares going to each of the partners is dependent on the production level. For increment up to 25,000 BOEPD, 75\% goes to EGPC. For increment exceeding 25,000 BOEPD, the ratio going to EGPC increases to $80 \%$.

7 During the exploration phase, the contractor should provide agreed numbers of EGPC employees to attend and participate in exploration and development operations and training programmes at a cost of $\$ 50,000$. 


\section{Appendix IV: Exploration and Production Blocks in Sudan}

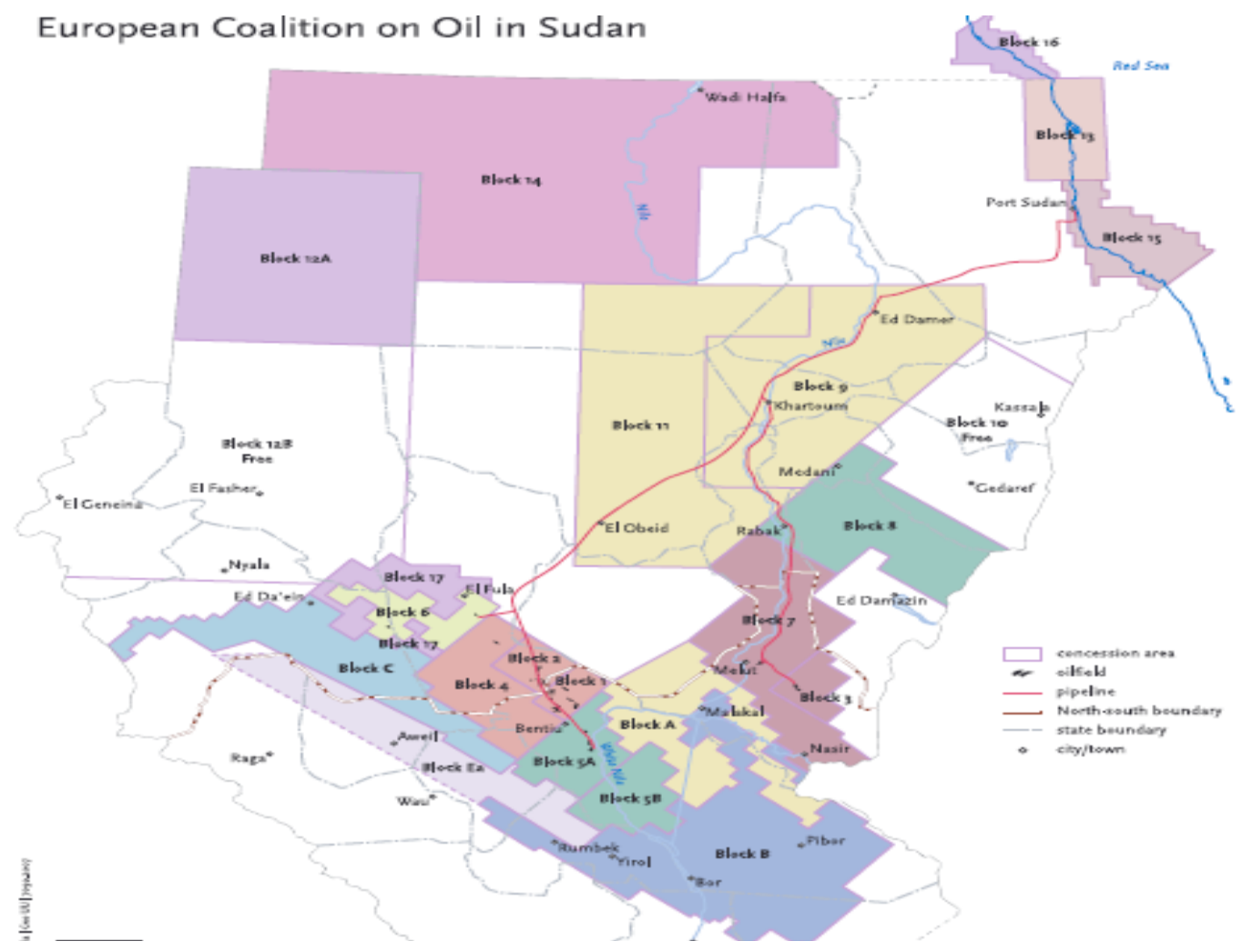

\begin{tabular}{|c|c|}
\hline Block 1,2,4 & CNPC (40\%), Petronas (30\%), ONGC (25\%), Sudapet (5\%) \\
\hline Block 3 \& 7 & CNPC (41\%), Petronas (40\%), Sudapet (8\%), Sinopec (6\%), Al Thani (5\%) \\
\hline Block 5A & Petronas (68.875\%), ONGC (24.125\%), ONGC $7(\%)$ \\
\hline Block 5B & GOSS, Petronas, Lundin, ONGC, Sudapet, Nilepet, Ascom \\
\hline Block 6 & CNPC (95\%), Sudapet (5\%) \\
\hline Block 8 & Petronas (77\%), Sudapet (15\%), Hi Tech (8\%) \\
\hline Block 9,11 & Zafir (85\%), Sudapet (15\%) \\
\hline Block 10 & Free \\
\hline Block 12A & $\begin{array}{l}\text { Qathani (33\%0, Ansan (20\%), Sudapet (20\%), Dindir Petroleum (15\%), Hi Tech (7\%), A.A. } \\
\text { In. (5\%) }\end{array}$ \\
\hline Block 12 B & Free \\
\hline Block 13 & $\begin{array}{l}\text { CNPC(40\%), Pertamina (15\%), Sudapet (15\%), Dindir Petroleum (10\%), Express } \\
\text { Petroleum\&Gas (10\%), Africa Energy (10\%) }\end{array}$ \\
\hline Block 14 & Petro SA (80\%), Sudapet (20\%) \\
\hline Block 15 & Petronas(35\%), CNPC (25\%), Sudapet (15\%), Express Petroleum \& Gas (10\%), Hi Tech (5\%) \\
\hline Block 16 & Lundin \\
\hline Block 17 & Ansan (66\%), Sudapet (34\%) \\
\hline Block A & Zafir (83\%), Sudapet (17\%) \\
\hline Block B & Total (32.5\%), Kufpec (27.5\%), Sudapet (10\%), GOSS (10\%), Open (20\%) \\
\hline Block C & Hi Tech (65\%), Sudapet (17\%), Khartoum State (10\%), Hegleig (8\%) \\
\hline
\end{tabular}

Source: European Coalition on Oil in Sudan 